\title{
A NEW SPECIES OF BRACHIONIDIUM (PLEUROTHALLIDINAE: ORCHIDACEAE) FROM THE HIGH MONTANE FOREST IN THE CENTRAL JUNGLE OF PERU
}

\author{
Luis ValenZuela GamarRa \\ Missouri Botanical Garden. Prolongación Bolognesi Mz. E Lote 6, Oxapampa-Pasco, Perú \\ luis_gin@yahoo.es
}

Abstract. A new species of Brachionidium was found on the highest mountains of the Central Jungle of Peru, on a wet Puna forest at $3470 \mathrm{~m}$ altitude. This species is similar to B. loxense and B. diaphanum but can be distinguished by its elliptic leaves with petioles $3-4 \mathrm{~mm}$ long; the short erect floral peduncle $2-3 \mathrm{~mm}$ long; the pink translucent sepals, red-wine toward the base; the floral bract spatuliform $15 \times 5 \mathrm{~mm}$; lip red-wine, bimarginated, trapezoidal, small, fleshy, obtuse acuminate, slightly prolonged lateral lobes antrorse and straight with a strongly pubescent cordate callus, split towards the apex.

Key words: Brachionidium, Central Jungle of Peru, Epidendreae, New species, Pleurothallidinae, Pui Pui Protection Forest, Wet puna forest

Introduction. In 1859 John Lindley described the genus Brachionidium from an excepcional collection of Restrepia parviflora Lindl. along with later collections of B. concolor Lindl. and B. tuberculatum Lindl. (Luer 1995). The name refers to the pair of tiny "arms" of the stigma that protrude from either side of the anther. The first reported number of pollinia in a species of the genus was six by Rolfe (1893) when he described B. sherringii Rolfe, the fourth species attributed to the genus, from the west of Indian island of Grenada. Schlechter in 1911 saw six pollinia in the peruvian $B$. serratum Schltr. Hoehne (1919) found 8 pollinia in a species of Brazil, and he described it as a new genus, Yolanda Hoehne, since he thought, Brachionidium had only 6 pollinia and Garay (1956) supported the classification, declaring that Brachinonidium was distinguished by 6 pollinia, and Yolanda by 8 pollinia. However, Luer (1995) made reviews on living material from several localities of Colombia and Ecuador, concluding that B. parvifolium (Lindl.) Lindl, the type species of the genus, definitely has 8 pollinia; he also examinated the pollinia of numerous other species described in his monography "Systematics of Brachionidium", indicating that six or eight pollinia are present.

The plants of the genus are variable in size and habits. The rhizomes repent to erect, branching, elongated between aerial stems (ramicauls), enclosed by a short, glabrous and scaly sheath, usually mucronate. The roots few to many, very close to the base or separated by the knots on the rhizomes thin to thick or fleshy. Ramicauls ascending to erect without pseudobulbs, unifoliate covered by 2 glabrous or scaly mucronous tubular sheaths. The inflorescences, lateral without an annular ring near the apex. Leaves erect in relation to the stem twigs, thick, smooth to rough, verrucous of green color to dark green sometimes stained of purple, elliptic, cuneate and narrow towards the anterior margin on the short petioles. Inflorescences, solitary with a not resupinated flower; peduncles longer or shorter than leaves, with a bract near the middle and another close to the base; floral bracts cucullated, inflated, acuminate, which surround the pedicel and much of the ovary; robust pedicel, with a filament much longer than the pedicel itself; trivalved soft ovary. Sepals conspicuous and membranous, of varied colors, soft, glabrous and frequently with tiny cilia, the middle sepal, free, usually downwards, acute to obtuse, the apex often ends in a thin tail; the lateral sepals connate in a sinsepal, generally upwards, free, acute to obtuse, the apex frequently acuminate and thin, sometimes ends in a bifid tail. Petals conspicuous, membranous, thin, similar to the sepals shortly ciliates, the apex acuminate, ends in a thin tail. Lip small, fleshy, transverse, the apex acute, obtuse to rounded, the soft margin to fimbriated and sometimes bimarginated with or without an apiculum, the disc more or less carinate 
or excavated anteriorly, with a flat ovoid, more or less pubescent callus in the center above the base, that fits under the column in normal position, the base is articulated to the apex of the column-foot. Column stout, short, semiterete, the anther and rostellum apical, the apical margin of the column bidentate, or smooth; the anther cap deciduous, 2-celled; the pollinia yellow, narrowly clavate-pyriform, more or less granular of 6-8, of unequal sizes distributed in two packets, often free, or attached to a detachable viscid viscidium; the stigma apical transversely bilobed, the receptive surface protruding to either side of the rostellar flap, sometimes on short, acute lobes or "arms", the base of the column forming a thick foot with the apex of the ovary (Luer 1995).

Currently according to Bogarín and Karremans (2016), the genus includes 80 species ranging from Guatemala to Bolivia and Brazil, throughout Central America, and the Antilles; the highest diversity is found in the highlands of Ecuador (34 species), Peru (15) and Colombia (12). On the other hand, Zelenko and Bermúdez (2009) indicate that there are 23 species to Peru. A review of botanical collections and records of the genus, including the major on-line databases (Bibliorchidea 2017, Epidendra 2017, Harvard Digital Collections 2017, IPNI 2017, Tropicos 2017), as well as the new additions by Bogarín and coworkers (2015), and Bogarín and Karremans (2016), Brachionidium reaches up to 82 species, from which 21 are recorded from Peru. These are: $B$. arethusa Luer and $B$. dalstroemii Luer from San Martín region; $B$. carmeniae Luer, $B$. diaphanum Luer \& R.Vásquez, B. elegans Luer \& Hirtz, B. inkaterrense Luer \& C.Soto, B. machupicchuense N.Salinas \& Christenson and B. phalangiferum Garay from Cusco region; $B$. ecuadorense Garay, B. galeatum Luer \& Hirtz, B. gonzalesii Becerra, B. quatuor Becerra, B. viridis Becerra \& Catchpole and B. yanachagaensis Becerra from Pasco region; B. ephemerum Luer \& Hirtz, B. muscosum Luer \& R.Vásquez and B. serratum Schltr. from Cajamarca region; B. parvum Cogn., $B$. tuberculatum Lindl. and $B$. piuntzae Luer from Huánuco; and B. furfuraceum Luer from Amazonas region.

Materials and methods. The description presented in the article is based on the available material of the new species that was found in the buffer zone of the Pui
Pui Protection Forest in the Marancocha community, Moyobamba district, Jauja Province, Region of Junín, Peru. The botanical collections were deposited in the MO, USM and HOXA herbaria. The description was made according to the morphological characteristics observed in the botanical collections; for this we used the species key for the genus proposed by Luer (1995) and additions by Becerra (2005), Becerra and Catchpole (2007), Luer (2010), Luer and Thoerle (2012), and Bogarín et al. (2015, 2016). The vegetative parts were examined using an Olympus stereoscope SZ4045 Stereozoom, 6.7 to 40x Magnification Range, a Leica optical microscope DM 300 (150x) and a digital microscope Celestron 44302B (250x). Digital photographs were used to document details of all the vegetative parts, the habit and the habitat; for this we use a digital camera SONY DSC-W210 Steady shot (12 MP 50x). Finally, we made the drawings of each detail observed, those that were used for the comparisons and discussions. Geographic coordinates were taken with a GPS 64 CSX to see the distribution of the species.

\section{TAXONOMIC TREATMENT}

\section{Brachionidium puipuiensis L.Valenz., sp. nov.}

TYPE: Peru. Junín: Jauja, Moyobamba, Marancocha community, in the buffer zone of the Pui Pui Protection Forest $11^{\circ} 18^{\prime} 39^{\prime \prime} \mathrm{S} 075^{\circ} 11^{\prime} 00.6^{\prime \prime} \mathrm{W}, 3740 \mathrm{~m}, 25$ octubre 2014, L. Valenzuela 28803, J. Flores, G. Shareba, H. Llantoy \& J. Doñe (holotype: HOXA; isotype: USM, MO). (Figs. 1-2).

Diagnosis. This species is similar to $B$. loxense and $B$. diaphanum but can be distinguished by its fleshy and elliptical leaves with petioles 3-4 $\mathrm{mm}$ long (vs. coriaceous and broadly elliptical to suborbicular leaves with petioles $1 \mathrm{~mm}$ long in $B$. loxense and erect, coriaceous, narrowly elliptical leaves with petioles $1.0-1.5 \mathrm{~mm}$ long in B. diaphanum); inflorescence peduncle 2-3 mm long ( $v s$. peduncle $10 \mathrm{~mm}$ long in $B$. loxense and 6-7 $\mathrm{mm}$ long in B. diaphanum); the pink translucent sepals, red-wine toward the base (rather than dark red purple, yellow towards the apex in $B$. loxense and translucent white in $B$. diaphanum); the floral bract spatuliform $15 \times 5 \mathrm{~mm}$ ( $v s$. protrunding filament 7-8 $\mathrm{mm}$ long in $B$. loxense and protrunding filament $4 \mathrm{~mm}$ long in B. diaphanum); lip, red-wine, bimarginated, 


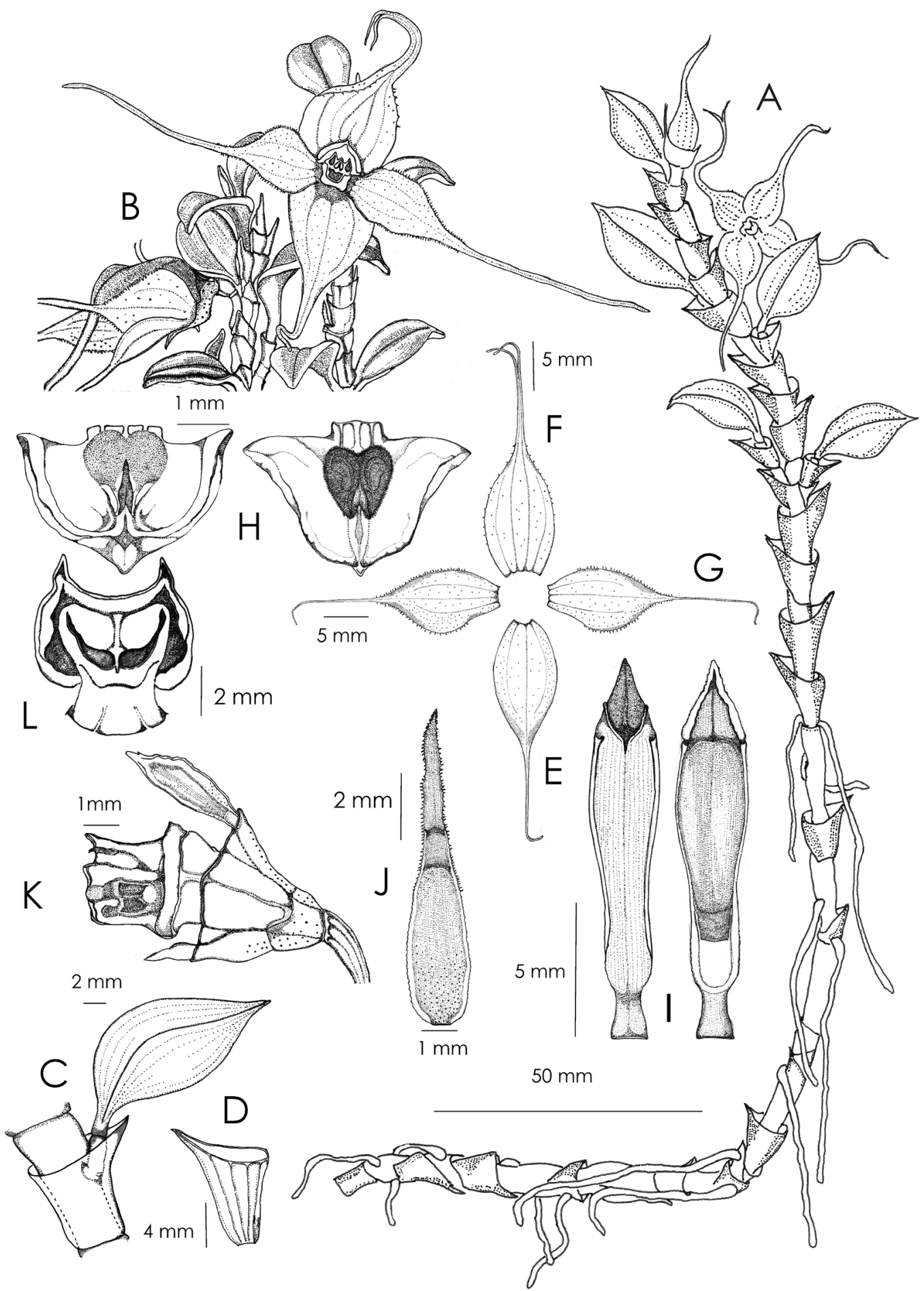

FIgURE 1. Brachionidium puipuiensis L.Valenz. A, Habit. B, Inflorescence. C, Leaf petiole and sheath. D, Sheath of ramicule. E, Midle sepal. F, Sinsepal. G, Petals. H, Lip (left, in fresh flower; right in dry flower). I, Floral bract. J, Atrophied flower. K, Column in lateral view. L, Column in frontal view. Drawn by the author from the holotype. 

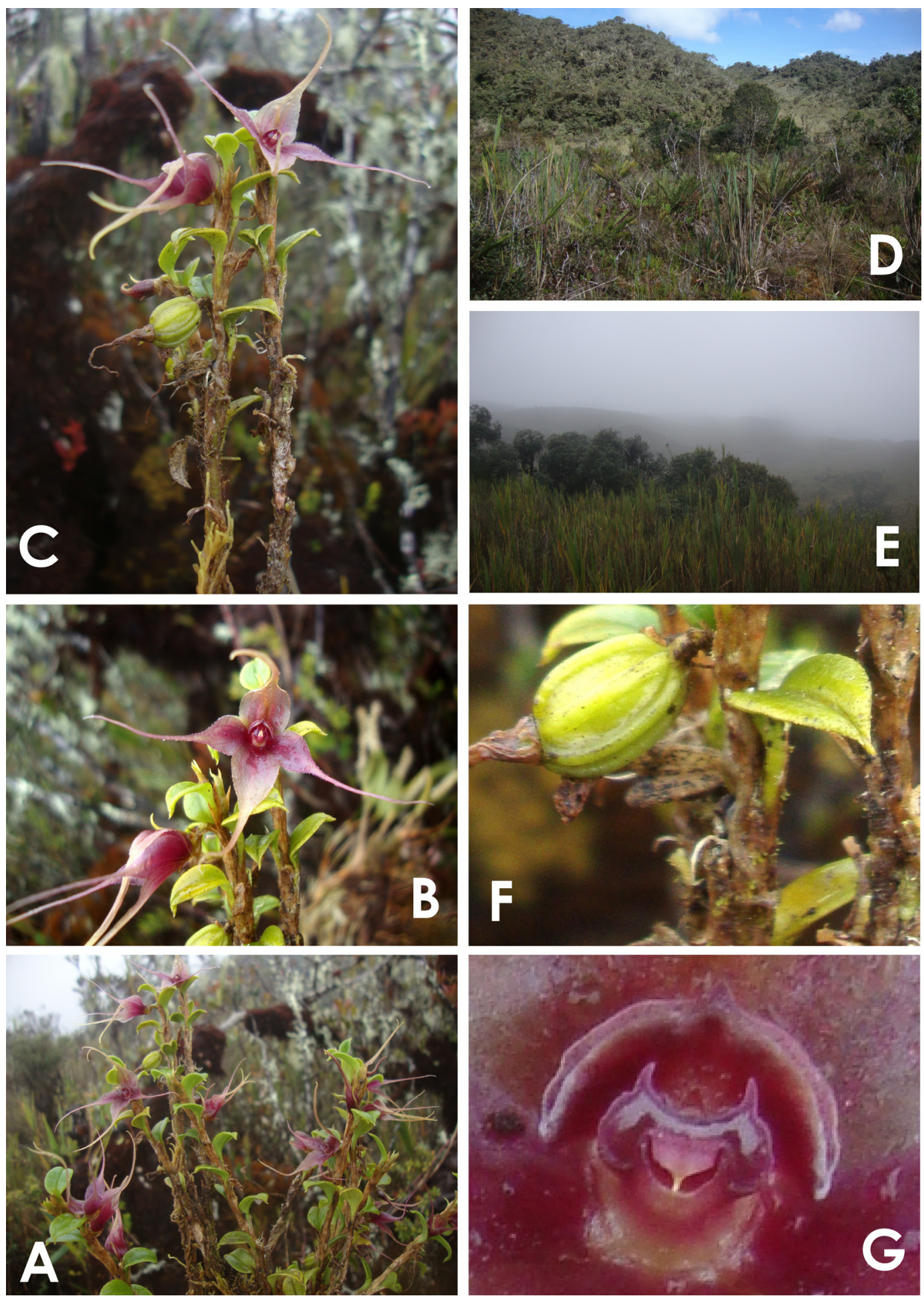

Figure 2. Brachionidium puipuiensis L.Valenz. A, Habit. B, Flowers. C, Flowered stem. D-E, Habitat. F, Fruit. G, Labellum and column. Photographs by the author from the plant that severed as type. 
trapezoidal, small, fleshy, obtuse acuminate $3 \times 4 \mathrm{~mm}$, with slightly prolonged lateral lobes, antrorse and straight with a cordate callus, split towards the apex (vs. yellow cream, transversely ovoide $3.5 \times 6.0 \mathrm{~mm}$, the lateral angles acute, subuncinate, the apex with an obtuse apiculum, the margins with low, longitudinal lamella-like calli, the disc with a central, flattened, minutely pubescent callus in $B$. loxense and yellow white, transversely oblong, concave $3 \times 7 \mathrm{~mm}$, lateral angles acute, incurved, the broadly rounded apex minutely apiculate, the margin with longitudinal calli, disc with an ovoid, flattened with a minute glenion in B. diaphanum).

Epiphytic herb up to $30 \mathrm{~cm}$ long, stems rhizomatous thick and erect $3 \mathrm{~mm}$ diameter. Ramicauls unifoliated 5-7 mm long, distance from one to another 10.0-10.3 $\mathrm{mm}$, covered by infundibuliform, acuminate sheaths, glabrous and translucent up to $10 \mathrm{~mm}$ long. Leaf fleshy, elliptic, $12-15 \times 4.5-5.0 \mathrm{~mm}$, with slightly apiculated apex, grooved petioles 3-4 mm long. Inflorescence terminal erect, protected by a bract cucullate, inflated, briefly acuminate $4 \mathrm{~mm}$ long, that surrounds the pedicel and ovary; the peduncle short, erect $2-3 \mathrm{~mm}$ long; pedicel thick $0.5-0.8 \mathrm{~mm}$ long. Flowers, pink translucent and red-wine towards the base, non-resupinated, protected by translucent bracts, one inserted near the base, spatuliform of $15 \times 5 \mathrm{~mm}$, shortly attenuated, with the margins slightly revolute, the other bract (atrophied flower) lanceolate and thin, $10.0 \times 1.2 \mathrm{~mm}$, margins roughly serrated towards the base. Sepals conspicuous and membranous; the dorsal sepal, acuminate, the base broad red-wine with 3 dark pink veins, the edge inconspicuously crenated $27 \times 6 \mathrm{~mm}$; the lateral sepals connate in an synsepal with 4 pink inconspicuous veins, $30.0 \times 5.7 \mathrm{~mm}$, the base broad and obtuse, pink translucent with the margin minutely serrulate, the apex acuminate with a slender tail bifid $15 \mathrm{~mm}$ long. Petals, conspicuous and thin, asymmetrical, pink translucent, the base wide, red-wine with 3 pink veins, $25 \times 5 \mathrm{~mm}$, strong edges and finely fimbriated, the apex acuminate in a long tail. Lip red-wine, bimarginated, trapezoidal, small, fleshy, obtuse acuminate $3 \times 4 \mathrm{~mm}$, slightly prolonged lateral lobes antrorse and straight with a heavily pubescent cordate callus, split towards the apex. Column red-wine thick, short, semi-erect $2 \mathrm{~mm}$ long; anther cover, deciduous with 2-celled. Pollinia, yellow
8, piriform nailed. Ovary, straight $5 \times 2 \mathrm{~mm}$ partially cover by a protective bract. Capsular fruits with six ribs $10 \times 5 \mathrm{~mm}$.

Etymology. The name refers to the place where the botanical sample was collected, alluding to the Pui Pui Protection Forest, protected natural area of the central region of Peru.

Distribution and Ecology. The species forms small colonies of 6-10 individuals. It was found in a forest of humid Puna, with abundant fog and constant drizzles, this forest is dominated by small trees of Polylepis spp. Escallonia myrtilloides, Myrteola phylicoides, Hesperomeles obtusifolia, Miconia salicifolia, Ilex ovalis, Hedyosmum cumbalense among others.

The species described is known only from the buffer zone of the Pui Pui Protection Forest, towards the eastern side, in the Central Jungle of Peru; the few populations are exposed to possible burnings of the forests, since the area is used for grazing. The author recommends the search of more populations near the studied area, to carry out processes of repopulation in similar places within the protected natural area.

ACKNOWLEDGEMENTS. The author thanks the management of SERNANP- Pui Pui Protection Forest, to José A. Ríos Suárez and Anamelva Zambrano Yaringaño for the facilities provided to access the protected area (Resolution $N^{\circ} 01-2014-S E R N A N P-$ JEF), to the Missouri Botanical Garden for the economic contribution, allowing scientific research in Peru, where many new taxa for science are discovered and described; to Rocío del Pilar Rojas Gonzáles for the respective procedures for obtaining the respective permits of law; to Cesar A. Rojas Tello for his help in transporting the scientific equipment to explore the area; to María Isabel Villalba Valdivia and Rodolfo Vásquez Martínez for their contributions to the manuscript. Finally, I would also like to thank to Hugo Llantoy and Jhojan Doñe, park rangers of the Pui Pui Protection Forest; Jaime Flores and Gerry Shareba field assistants from the Missouri Botanical GardenPeru and to Mr. Agustín Artiaga and Francisco Canchumania local assistants from the rural community of Toldopampa.

\section{Literature Cited}

Becerra, E. (2005). El género Brachionidium (Orchidaceae) en el Perú. Tres especies nuevas para la selva central peruana. Arnaldoa, 12(1-2), 54-61.

Becerra, E. \& Catchpole, D. J. (2007). The genus 
Brachionidium Lindl. (Orchidaceae) in Peru with a new species endemic to the Selva Central. Lindleyana, 76(17), 937-939.

BibliOrchidea. (2017). Swiss Orchid Foundation at the Herbarium Jany Renz, University of Basel.

Bogarín, D., Karremans, A. P. \& Muñoz García, M. (2015). Brachionidium kirbyi, eine neue Art zu Ehren des Gründers des Orchideenprojektes "Bosque de Paz" in Costa Rica. Die Orchidee, 66, 404-409.

Bogarín D. \& Karremans, A. P. (2016). A New Brachionidium (Orchidaceae: Pleurothallidinae) from the First Botanical Expedition to the Volcán Cacho Negro, Costa Rica. Systematic Botany, 41(4), 919-923.

Epidendra. (2017). The Global Orchid Taxonomic Network. Jardín Botánico Lankester, Universidad de Costa Rica. Available from http://epidendra.org/taxones/index. html. Consulted on January 2017.

Garay, L. A. (1956). Studies in American orchids, II. The genus Brachionidium Lindl. Canadian Journal of Botany, 34, 721-743.

Harvard Digital Collections. (2017). Harvard University Herbaria and Libraries. Available from http://www.hcl. harvard.edu/. Consulted on January 2017.

Hoehne, F. C. (1919). Yolanda - Gen. nov. In: Museu Nacional (Brazil), Arquivos do Museu Nacional do Rio de Janeiro Vol. XXII (72-73). Rio de Janeiro: Imprensa Nacional.

IPNI. (2017). The International Plant Names Index. Available from http://www.ipni.org/. Consulted on January 2017.

Lindley, J. A. (1859). Brachionidium. In: Matthews, J. (Ed.), Folia Orchidacea. An Enumeration of the Known Species of Orchids (Fasc. 8-9). London: Bradbury \& Evans.
Luer, C. A. (1995). Icones Pleurothallidinarum XII. Systematics of Brachionidium and addenda to Dresslerella, Platystele and Porroglossum (Orchidaceae). Monographs in Systematic Botany From the Missouri Botanical Garden, 57, 1-138.

Luer, C. A. (2010). Icones Pleurothallidinarum XXXI. Addenda: new species of Brachionidium, Lepanthes, Masdevallia, Octomeria, Platystele, Pleurothallopsis and Porroglossum. Monographs in Systematic Botany from the Missouri Botanical Garden, 120, 137-153.

Luer, C. A. \& Thoerle, L. (2012). Miscellaneous new species in the Pleurothallidinae (Orchidaceae). Harvard Papers in Botany, 17, 333-368.

Rolfe, A. R. (1893). Brachionidium sherringii Rolfe. In: Bulletin of Miscellaneous Information (Royal Botanic Gardens, Kew). London: H.M. Stationery Office,1900-1941. Recovered from http:// biodiversitylibrary.org/page/41012310

Schlechter, R. (1911). Orchidacae novae et criticae. In: Friedrich Fedde, P. (Ed.), Repertorium Specierum Novarum Regni Vegetabilis Fasciculus IX (161-166). Berlin: Selbstverlag des Herausgebers. Recovered from http://biodiversitylibrary.org/page/231270

Schweinfurth, C. (1959). Orchids of Peru. Fieldiana, 30, 533-786.

Schweinfurth, C. 1970. Orchids of Peru. Fieldiana, 33, $1-80$.

Tropicos. (2017). Missouri Botanical Garden. Available from http://www.tropicos.org/. Consulted on January 2017.

Zelenko, H. \& Bermúdez, P. (2009). Orchids: species of Peru. Quito, Ecuador: ZAI Publications. 